\title{
Aspek Hukum Pengawasan pada Perbankan Syariah di Indonesia
}

\author{
Bagya Agung Prabowo
}

\begin{abstract}
Islamic Banking can only developed if investor and customers prefer to use Islamic Banks over conventional bank. The Islamic Banks are required to consider the interests of both investor and customers, as well as the need to maintains their trust. In order to promote the Islamic Banking credibility, the Islamic Banking needs a direct control from the BI (Bank Indonesia) and the DPS (Dewan Pengawas Syariah). This mechanism is very important In one hand $B /$ as control bank in Indonesia can maintain and control CAR (Capital Adequate Ratio) on the other hand, the DPS has as authanity to control subtansial aspects of syariah.
\end{abstract}

\section{Pendahuluan}

Bank Indonesia (BI) sebagai Bank Sentral bertanggungjawab melakukan pengawasan perbankan, ' belakangan ini tengah melakukan penyempurnaan sistem pengawasan bank, dari sistem compliance (kepatuhan pada regulasi) menjadi pengawasan berdasarkan risiko (risk based supervision). Hal ini dimaksudkan untuk mengetahui permasalahan bank sejak dini. Selama ini, BI melakukan pengawasan reaktif, yakni berdasarkan peraturan saja (compliance), sehingga jika ada permasalahan di sebuah bank; baru diketahui kemudian.

Karakteristik dari pengawasan reaktif adalah apabila muncul suatu masalah baru dilihat regulasinya. Dengan penyempumaan pengawasan berdasarkan risiko ini, permasalahan suatu bank sudah dapat

dideteksi sejak dini (pro-aktif), sehingga langkah solusinya dapat cepat diketahui. Pendekatan pengawasan bank berbasis risikoini termasuk pemahaman yang lebih baik terhadap kualitas manajemen, karakteristik bisnis, dan risiko yang dihadapi bank. ${ }^{2}$ Dengan pengawasan semacam itu memungkinkan $\mathrm{BI}$ menunjukkan konsistensi dalam melaksanakan tanggung jawab pengawasannya, sehingga dapat mengambil keputusan secara lebih sistematis dalam menilai bank yang layak beroperasi.

Hampir tidak ada yang menyanggah pendapat yang mengatakan bahwa baik buruknya sistem perbankan sangat bergantung pada sejauh mana kekuatan pengawasan terhadap bank-bank dilakukan. ${ }^{3}$ Memang, bila dikaji lebih jauh, akar permasalahan dari

'Bank Indonesia, Hal-hal Pokok Dalam Undang-undang No. 7 Tahun 1992 Tentang Perbankan (Jakarta: tp, 1992, him. 6).

${ }^{2}$ Afif, Faisal, dkk., Strategi dan Operasioan/Bank, Bandung: Eresco, 1996, hlm. 23

3Djumhana, Muhammad, Hukum Perbankan di Indonesia, Bandung: Citra Aditya Bakti, 1989, hlm. 12. 
kerusakan tatanan sistem perbankan di Indonesia selama ini sebenarnya berkaitan erat dengan lemahnya sistem pengawasan perbankan yang diemban oleh BI. Akselerasi perkembangan dunia perbankan yang demikian pesatnya (ditandai dengan pertumbuhan aset dan kantor cabang yang fantastik) tanpa diimbangi dengan pengawasan yang baik akan menghasilkan pengawasan yang tidak efektif.

Kondisi semacam itu yang dialami BI saat ini, sehingga akhirnya banyak bank yang terbengkalai atau tidak terawasi dengan baik. Dampaknya jelas, akhirnya banyak yang ditutup (likuidasi, BBKU, atau BBO): Padahal, industri perbankan merupakan industri yang membutuhkan pengawasan ekstra ketat, mengingat dana yang tersimpan adalah milik masyarakat. Tidak mengherankan apabila mengacu pada Undang-Undang (UU) Nomor 23 Tahun 1999 tentang Bank Indonesia, yang menyebutkan bahwa kelak di masa mendatang, tugas pengawasan bank ini akan dilakukan oleh lembaga pengawas independen Otoritas Jasa Keuangan (OJK) dan keberadaannya dibentuk dengan undangundang (Pasal 34). Bahkan dikatakan bahwa pembentukan lembaga pengawas itu akan dilaksanakan selambat-lambatnya tanggal 31 Desember 2002.

Porsi inilah yang nantinya akan diberikan kepada OJK. Dengan demikian, langkah pengawasan pro-aktif yang sudah dirintis oleh Bl ini, setidaknya akan menjadi pegangan utama yang akan diteruskan oleh OJK. Dengan demikian, BI akan dapat lebih memfokuskan perhatian pada aspek penataan moneter (kebijakan moneter) dan lalu lintas (kelancaran) sistem pembayaran, ketimbang pengawasan bank-bank.

Di beberapa negara maju, aspek pengawasan ini memang dilakukan oleh lembaga independen lain, terutama untuk menghindari konflik kepentingan antara bank sentral sebagai pengatur bank sekaligus sebagai pengawas bank. ${ }^{4}$ Fenomena inilah sebenarnya yang justru teramat penting dan cenderung diabaikan orang, di tengah pengawasan intensif terhadap 14 bank yang menguasai 70 persen pasar. Terlebih pemerintah saat ini tengah membangun sistem perbankan yang sehat dan profesional. Untuk itulah, masalah pengawasan bankbank menjadi sangat penting dan memiliki tingkat urgensitas yang tinggi.

\section{Arti Penting Pengawasan}

Ada beberapa alasan mengapa terhadap lembaga perbankan perlu diterapkan pengawasan secara khusus, tidak sebagaimana lembaga keuangan lain maupun badan-badan usaha lainnya.

Pertama, lembaga perbankan mempunyai posisi yang sangat strategis dalam pembangunan nasional. Hal ini dapat dimengerti, karena perbankan sebagai salah satu penggerak roda perekonomian dan pendukung utama pelaksanaan kebijaksanaan moneter yang efektif di Indonesia.

Kedua, dari pengertian bank sebagai lembaga, menurut Undang-undang No. 23

"Pardede, Marulak, "Tinjauan Terhadap Metoda Bank Indonesia Dalam Menciptakan Perbankan yang Profesional dan Sehat," NewsletterNo. 19N/Desember/t994, him. 9. 
Tahun 1999 tentang Bank Indonesia adalah badan usaha yang menghimpun dana dari masyarakat dalam rangka meningkatkan taraf hidup rakyat banyak. Dari pengertian tersebut dapat dipahami bahwa bank dalam operasionalisasi usahanya pada dasarnya memanfaatkan dana dari masyarakat penyimpan untuk masyarakat peminjam. ${ }^{5}$ Hal ini ditegaskan pula oleh penjelasan Undang-undang No. 23 Tahun 1999 tentang Bank Indonesia yang mengemukakan bahwa bank terutama bekerja dengan dana dari masyarakat yang disimpan pada bank atas dasar kepercayaan. Sebelum berlakunya Undang-undang No. 23 Tahun 1999 tentang Bank Indonesia di atas, berdasarkan Paket Februari 1991 mengenai Kewajiban Penyediaan Modal Minimum, atau dikenal dengan Capital Adequat Ratio (CAR), sejalan dengan standar yang ditetapkan oleh Bank for International Settlements (BIS) terhadap seluruh bank dibebani sebesar $8 \%$ dari Aktiva Tertimbang Menurut Risiko (ATMR). Dengan demikian, dalam pengoperasian suatu bank dapat dikatakan $92 \%$ dananya milik masyarakat, sedangkan modal Bank sendiri hanya $8 \%$-nya. ${ }^{6}$

Ketiga, lembaga perbankan adalah lembaga yang mengandalkan kepercayaan masyarakat. Artinya, apabila sampai terjadi masyarakat kehilangan kepercayaan terhadap bank, di mana salah satu indikasinya bila terjadi rush atau penarikan dana simpanan secara serentak oleh para nasabah, maka akan menyebabkan dunia perbankan tidak. dapat mengoperasikan usahanya.

Pada gilirannya dunia perbankan tidak lagi mampu menopang berjalan efektifnya kebjjakan moneter yang ada. Sebagaimana dikutip oleh Sutan Remi Sjahdeni dari pendapat Simon jr. bahwa hubungan antara bank dengan nasabah bukan sekedar hubungan debitur-kreditur semata, tetapi juga suatu fiduciarty relationship. Mengingat bank adalah a place of special safety and profity. ${ }^{\circ}$ Apabila sampai terjadi kepercayaan. masyarakat terhadap perbankan hilang, maka dapat menimbulkan akibat-akibat yang sangat berat konsekuensinya bagi dunia perbankan. Salah satu diantaranya yaitu hilangnya kesediaan masyarakat untuk menyimpan dananya di bank. Hal ini akan menyebabkan melemahnya kemampuan bank dalam memenuhi kebutuhan dana untuk membiayai kegiatan perekonomian. Hilangnya kepercayaan masyarakat pada suatu bank yang kemudian mengalami keruntuhan, menyebabkan timbulnya keraguan masyarakat. kepada bank-bank yang lain atau kepada perbankan pada umumnya.

5Remi Sjahdeni, "Bank Indonesia Penggerak Utama Reformasi Peraturan Perundangan Perbankan," Orasi, UNAIR, Suarabaya, 1996, hlm. 8.

'Surat Edaran BI No. 26/1/BPPP, 1993, him. 7.

${ }^{7}$ Rahman, Hasanudin, Aspek-aspek Hukum Pemberian Kredit Perbankan di Indonesia, Bandung: Citra Aditya Bhakti, 1995, hlm. 7.

'Sutan Remi Sjahdeni, "Sudah Memadaikah Perlindungan Yang Diberikan Oleh Hukum Kepada Nasabah Penyimpan Dana," Orasillmiah Dies Natalis XLL ustrum VIII UNAIR, Surabaya, 1994, hIm. 3. 


\section{Tujuan Pengawasan Perbankan}

Dari pengertian pengawasan perbankan di atas dikaitkan dengan arti pentingnya pengawasan perbankan, maka dapat diambil garis tegas mengenai tujuan dari pengawasan perbankan. Secara umum dapat dikatakan bahwa pengawasan perbankan dimaksudkan untuk meningkatkan keyakinan dari semua pihak yang berkepentingan. ${ }^{9}$

Tiga hal yang diperhatikan dalam pengawasan bank adalah: Pertama, bahwa dari segi finansial tergolong sehat; Kedua, bank dikelola secara baik dan profesional; Ketiga, bahwa di dalam bank tidak terkandung segi-segi yang merupakan ancaman terhadap kepentingan masyarakat yang menyimpan dananya di bank. Tujuan pengawasan perbankan sebagaimana di atas banyak dijumpai dalam praktik perbankan di negaranegara lain.

Perhatian utama pengawasan tersebut lebih banyak ditekankan pada aspek intemal bank agar dapat melindungi pengembalian dana masyarakat yang dipercayakan kepadanya.$^{10}$ Artinya pengawasan perbankan hanya merupakan suatu upaya untuk memberikan jaminan akan keamanan ataupun pengembalian dana masyarakat yang disimpan di dalam bank. Di Indonesia sebagaimana dituangkan dalam ketentuan perundang-undangan mengenai Bank Indonesia secara terperinci disebutkan bahwa tujuan diselenggarakannya pengawasan dan pembinaan bank ialah dalam rangka mewujudkan sistem perbankan yang sehat dan efesien." Dalam arti, dapat memelihara kepentingan masyarakat dengan baik, berkembang secara wajar dan bermanfaat bagi perkembangan ekonomi Indonesia. Untuk mendúkung tercapainya tujuan tersebut maka diperlukan faktor-faktor yang dapat menunjang antara lain berupa:

a. Perbankan yang dinamis dan profesional serta mampu menciptakan produk-produk baru yang dibutuhkan oleh masyarakat.

b. Persaingan antar bank yang sehat.

c. Iklim yang mendorong perluasan jaringan perbankan yang dapat menjangkau masyarakat luas di seluruh pelosok tanah air.

d. Pemerataan pembangunan ekonomi di berbagai sektor dan daerah.

e. Kebijaksanaan di bidang pengawasan dan pembinaan bank yang memungkinkan terciptanya faktor-faktor tersebut di atas serta mampu mendorong terwujudnya bank yang sehat dari sudut permodalan dan keuangan serta kualitas asset dan manajemen.

f. Dasar Hukum Pengawasan Perbankan

Sebagai lembaga kepercayaan yang dalam usahanya terutama menggunakan dana masyarakat, kesehatan suatu bank merupakan kepentingan dari semua pihak

'Subardjo Joyo Sumarto, Pengawasan dan Pembinaan Bank, (Jakarta: Bank Indonesia, 1993), hlm. 5.

${ }^{10} /$ bid., hlm. 16.

"Muhammad Hadi Subhan, Rentabilitas Perbankan Dengan Sistem Bagi Hasil dan Relevansi Asas Kehati-hatian Dalam Proses Pemberian Kredit Tanpa Agunan, (Surabaya: FH. UNAIR, 1994). 
yang terkait, baik pemilik dan pengelola bank, masyarakat pengguna jasa bank maupun Bank Sentral selaku pengawas dan pembina bank. ${ }^{12}$ Dengan demikian, kesehatan bank dapat tercapai apabila semua pihak yang berkepentingan tersebut bersama-sama berupaya untuk mewujudkannya. Untuk itu pihak-pihak tersebut perlu menyadari hak dan tanggung jawabnya serta mengikatkan diri (commited) untuk melaksanakan dengan baik, sesuai asas-asas perbankan yang sehat. ${ }^{13}$

. Hak dan kewajiban dari masing-masing pihak tersebut dalam garis besarnya adalah sebagai berikut :

a. Pemilik sebagai penanggung atas modal yang ditanamkannya mempunyai hak atas deviden dan nilai tambah modal serta memilih pimpinan bank yang profesional dan bermoral tinggi. Dengan demikian untuk mewujudkan bank yang sehat, pemilik tidak boleh memanfaatkan bank melalui perlakuan khusus dalam bidang perkreditan maupun jasa-jasa bank lainnya. ${ }^{14}$

b. Pimpinan dan karyawan sebagai pelaku dan penggerak dari organisasai bank berhak menetapkan dan melaksanakan kebijaksanaan operasi bank secara profesional. Untuk itu yang bersangkutan wajib memenuhi nomanorma profesionalisme yang berlaku di bidang perbankan dan ketentuan-ketentuan tentang pengelolaan bank yang dikeluarkan oleh Bank Sentral, sehingga kepentingan masyarakat pada bank dapat terlindungi.

c. Masyarakat pengguna jasa bank berhak memperoleh pelayanan yang sebaikbaiknya dan jaminan keamanan atas dana yang dipercayakan pada bank. Dalam hubungan ini kreditur perlu mengetahui secara seksama hak dan kewajibannya sebagai nasabah dan di lain pihak debitur dan pengguna jasa lainnya wajib memenuhi kewajiban-kewajibannya kepada bank sesuai dengan hal-hal yang telah diperjanjikan.

d. Pihak-pihak lain yang terkait termasuk akuntan publik yang dapat menunjang tercapainya kesehatan bank melalui penerapan prinsip-prinsip akuntansi perbankan dan masyarakat pada umumnya melalui informasi yang objektif.

e. Bank Sentral sebagai pengawas dan pembina bank berkewajiban menciptakan iklim dan landasan yang memungkinkan terlaksananya mekanisme tersebut di atas serta menciptakan sistem pengawasan dan pembinaan bank-bank yang efektif guna mendorong terwujudnya perbankan yang sehat.

Atas dasar tujuan dan pola pendekatan tersebut di atas, terdapat beberapa aspek strategis yang perlu ditempuh oleh BI dalam melakukan pengawasan dan pembinaan bank-bank, sehingga tercapainya perbankan yang sehat direalisasikan dengan lebih efektif: ${ }^{15}$

${ }^{12}$ Warkum Sumitro, Ásas-asas Perbankan Islam Dan Lembaga-lembaga Terkait Di Indonesia (Jakarta: Raja Grafindo Persada, 1992), him. 29.

${ }^{13}$ Himpunan Ketentuan lanjutan Paket Oktober, 1991, hlm. 37.

14Suradi, "Peranan Bank Perkreditan Rakyat Berdasarkan Prinsip Bagi Hasil Bagi Pengusaha Kecil di Daerah Istimewa Yogyakarta," Tesis, Program Pasca Sarjana UGM, Yogyakarta, 1997, hlm. 14. 15Wijanarko, Hukum dan Ketentuan Perbankan dilndonesia (Jakarta: Grafiti, 1993), him. 26. 
a. Perubahan pola pikir pihak-pihak yang terkait dengan upaya peningkatan kesehatan bank, meliputi:

1) Perubahan pola pikir dan sikap pemilik bank.

2) Peningkatan profesionalisme di bidang perbankan.

3) Penerapan kode etik di bidang perbankan.

4) Peningkatan bank mindedness.

5) Penerapan standar akuntasi di bidang perbankan.

6) Penerapan otomatisasi dan pemanfaatan sistem informasi.

b. Penyesuaian sistem pengawasan dan pembinaan bank dalam era deregulasi, meliputi:

1) Landasan hukum terutama yang bertalian dengan prudential regulation dan sanksi atas pelanggarannya.

2) Sarana penunjang peningkatan efesiensi dan kelancaran usaha bank.

3) Sistem deteksi dini.

4) Sistem pemeriksaan.

5) Upaya yang berkesinambungan dalam memenuhi kualitas maupun kuantitas pengawas dan pemeriksa bank serta penggunaan kemajuan teknologi.

6) Desentralisasi pengawasan dan pembinaan bank.

c. Sistem Pengawasan dan Pembinaan Perbankan

Untuk mewujudkan sistem perbankan yang sehat dan efesien dengan pola pendekatan dan dengan berpedoman pada strategi sebagaimana dikemukakan di atas, sistem pengawasan dan pembinaan bank-bank di susun dengan menggunakan jalur yang terdiri dari beberapa komponen:16

1) Landasan Operasional yang Harus Ditaati Oleh Dunia Perbankan

Landasan operasional diperlukan untuk dapat dijadikan pedoman bagi bank-bank dalam menjadikan dirinya sebagai lembaga perantara di bidang keuangan yang dapat dipercaya. Oleh karena itu landasan operasional bagi bank dimulai sejak awal pendirinya dalam bentuk ketentuan perijinan dan dilanjutkan dengan pedoman operasional berupa prinsip kehati-hatian yang perlu dipenuhi dalam melakukan perluasan usaha dan pedoman untuk mempertahankan tingkat kesehatan.

2) Mekanisme Pengawasan yang Memungkinkan Deteksi Dini

Untuk memungkinkan dilakukannya deteksi dini, pengawasan dilaksanakan dengan menggunakan laporan-laporan yang disampaikan oleh bank-bank, informasi yang bersumber dari saranasaranan penunjang kegiatan bank, informasi yang berasal dari sumbersumber lainnya: Dari laporan-laporan bank yang disusun secara benar dan tepat waktu dapat dilakukan pengamatan mengenai perkembangan, keadaan keuangan dan pola pokok operasionalnya bank.

3) Metode Pemeriksaan yang Dapat Mengungkapkan Kondisi Bank Secara Objektif

18/bid., him. 31. 
Untuk memperoleh hasil pemeriksaan yang objektif, diperlukan:
a) Cara penilaian aktiva produktif yang didasarkan pada faktor kualitatif dan kuantitatif.
b) Cara pemeriksaan yang antisipatif terhadap kegiatan dan produk-produk baru.
c) Cara pemilihan yang tepat dari objek pemeriksaan, waktu pemeriksaan dari penentuan sample bank dan kantor yang diperiksa.

d) Cara evaluasi hasil pemeriksaan yang konsisten sehingga dapat menghasilkan kesimpulan yang tepat.

e) Laporan pemeriksaan yang objektif dan tepat waktu. Metode pemeriksaan tersebut harus ditunjang oleh tersedianya pemeriksa bank yang cukup jumlahnya, dengan kualitas yang baik dalam arti cakap, berdedikasi, mempunyai integritas dan moral yang tinggi.

\section{4) Mekanisme Pembinaan Secara Efektif}

Mekanisme pembinaan yang efektif mengandung dua aspek penting, yaitu komunikasi yang terbuka dan cara pemecahan masalah yang tepat. Untuk itu, 'maka hasil deteksi dini dan hasil pemeriksaan perlu dimanfaatkan secara tepat dalam rangka pembinaan bank.

\section{5) Penerapan Sanksi dan Metode Penyelesaian masalah}

Sanksi dapat berupa sanksi yang formal maupun sanksi yang didasarkan kepada kasus-kasus yang diterapkan atas dasar hasil pembinaan tersebut pada huruf d. Sanksi formal dapat berupa denda atau sanksi administratif. Oleh karena itu, secara kasuistis dapat dilakukan penerapan sanksi seperti pembatasan pendirian kantor baru, perluasan jenis usaha dan ekspansi kredit, penggabungan usaha bank dan atau pengalihan sebagian atau keseluruhan saham bank kepada investor baru merupakan alternatif penyelesaian masalah yang dapat ditempuh.

\section{6) Sarana Penunjang.Peningkatan Efesiensi dan Kelancaran Usaha Bank}

Di samping jalur pengawasan dan pembinaan yang berkaitan langsung dengan bank-bank secara individual, diperlukan sarana penunjang dalam rangka peningkatan efesiensi dan kelancaran usaha bank maupun dalam rangka perubahan pola pikir pihakpihak yang terkait dengan upaya peningkatan kesehatan bank. Sarana penunjarig ini dapat berupa lembaga pelayanan seperti kliring, sistem informasi kredit, serta pasar uang dan pasar valuta asing, maupun dalam bentuk dorongan untuk menciptakan kondisi yang menjurus kepada kesamaan pola pikir. Oleh karena itu, penyebaran pemahaman tentang fungsi dan peranan bank merupakan upaya yang periu dilakukan secara berkesinambungan.

Efektivitas sistem pengawasan dan pembinaan bank melalui 6 jalur tersebut di atas perlu ditunjang oleh prinsip:

a. Desentralisasi dalam pelaksanaan pengawasan dan pembinaan bank. Dengan demikian komunikasi timbal balik anatara BI selaku pengawas dan pembina bank dengan dunia perbankan dan pihakpihak lain yang berkepentingan; seperti Dewan Syariah yang juga sebagai pengawas dan pembina Bank Syariah 
dapat berjalan dengan cepat, lancar dan objektif.

b. Kaderisasi dan peningkatan kualitas yang terus-menerus dari pelaksanaan pengawasan dan pembinaan bank.

\section{Ketentuan Perbankan yang Sehat}

Melalui Paket Februari 1991 tersebut telah diperkenalkan asas atau prinsip kehati-hatian, yaitu suatu asas yang sangat penting sebagai pedoman operasi perbankan yang berlaku bagi perbankan di seluruh dunia. Sebagai penjabaran dari prinsip kehati-hatian tersebut, dengan Paket Februari 1991 itu telah dipancangkan berbagai rambu yang merupakan prudential standart yang harus diperhatikan oleh perbankan yang terdiri atas rambu-rambu keseluruhan. Paket Februari 1991 merupakan upaya pemerintah untuk memperkuat sistem perbankan Indonesia dan memutakhirkan (up to date) ketentuanketentuan perbankan Indonesia agar konsisten dengan standar intemasional di bidang perbankan sebagaimana telah ditetapkan oleh Bank for International Settlements (BIS).

Setelah dikeluarkannya Undang-undang No. 7 Tahun 1992 tentang Perbankan, maka prinsip kehati-hatian dan berbagai rambu di dalam Paket Februari 1991 tersebut telah diambil alih dan dimasukkan ke dalam Undangundang tersebut. Selain itu, dalam Undangundang Nomor 7 Tahun 1992 telah dimuat juga asas-asas lain dan rambu-rambu selain dari asas kehati-hatian di dalam Paket Februari 1991, yang kini juga dicantumkan dalam Undang-undang No. 23 Tahun 1999 tentang Bank Indonesia.

Demikian halnya, agar bank tersebut tidak melakukan kegiatan-kegiatan yang hanya bertujuan untuk memempercepat ekspansi assetnya tanpa didukung sama sekali oleh keuangan yang berasal dari modalnya sendiri. Ketentuan batas minimum CAR ini menjadi kendali bagi penetapan Batas Maksimum Pemberian Kredit atau Legal Lending Limit. ${ }^{17}$ Selain harus memenuhi batas penetapan minimum CAR, bank juga harus memperhatikan penetapan batas minimum Loon to Deposit Ratio, yaitu perbandingan antara kredit yang dapat diberikan oleh bank itu dibandingkan dengan jumlah dana simpanan pihak ketiga yang dikerahkan oleh bank tersebut.

Berdasarkan ketentuan yang tertuang dalam Surat Edaran BI No. 26/5/BPPP tanggal 29 Mei 1993 besarnya Loon to Deposit Ratio ditetapkan tidak boleh melebihi $110 \%$. Dengan ditetapkannya rambu-rambu berupa Batas Maksimum Pemberian Kredit dan Loon Deposit Ratio yang harus diperhatikan oleh setiap bank dalam operasi perkreditannya, maka bank tidak dapat begitu saja secara semena-mena melakukan ekspansi kredit dengan hanya bertujuan untuk secepatnya membesarkan jumlah assetnya, karena hal itu akan menimbulkan bahaya bagi kelangsungan hidup bank tersebut.

Penilaian tingkat kesehatan bank sebagaimana ditetapkan dalam SK Direksi BI No. 26/23/KEPIDIR dari Surat Edaran BI No.26/ 5/BPPP perihal Tàta Cara Penilaian Tingkat Kesehatan Bank Perkreditan Rakyat, bahwa

${ }^{17}$ Abdul Qadir, Banaga, Graham H. Ray, CyrilR, Tom Kins, Ekstemal Audit And Comorate Govemance In Islamic Banks : A Joint Practitioner Academic Research (Ttp:Ashgate Publishing Company, 1994), him. 19. 
faktor-faktor penilaian kesehatan bank adalah permodalan (capita), kualitas aktiva produktif (asset quality), kualitas manajemen (management quality), rentabilitas (eamings) dan liquiditas (liquidity) yang keseluruhannya dikenal dengan istilah Camel. Faktor lain yang dapat mempengaruhi penilaian tingkat kesehatan suatu bank adalah faktor judgement yang mencakup penilaian inkonsistensi dalam Camel dan perselisihan intern, campur tangan pihak ketiga, windows dressing, bank dalam bank, dihentikannya bank dalam kegiatan kliring.

Di samping faktor-faktor tersebut di atas, sebagai faktor penunjang, bank harus memenuhi ketentuan-ketentuan mengenai Batas Maksimum Pemberian Kredit (BMPK), sebagaimana diatur dalam SK Direksi BI dan Surat Edaran mempunyai pengertian batas maksimum penyediaan dana yang diperkenankan untuk diberikan oleh bank kepada peminjam tertentu. Dalam hal ini yang dimaksud dengan penyediaan dana adalah pemberian fasilitas kredit, fasilitas jaminan, pembelian surat berharga, atau hal lain yang serupa, yang dapat dilakukan oleh bank kepada peminjam atau kelompok peminjam. Ketentuan. mengenai Batas Maksimum Pemberian Kredit ini merupakan ketentuan pelaksanaan dari Pasal 11 Undang-undang No. 7 Tahun 1992 tentang Perbankan yang kini juga diatur dalam Undang-undang No. 23 Tahun 1999 tentang Bank Indonesia. Batas Maksimum Pemberian Kredit bagi satu peminjam yang tidak terkait dengan bank atau perorangan dan bagi satu kelompok peminjam yang tidak terkait dengan bank yang pelaksanaannya dilakukan secara bertahap.

Dengan ketentuan ini diharapkan, bank yang melakukan kegiatan usahanya, terutama dengan menggunakan dana masyarakat yang dipercayakan kepadanya, dapat menjaga dan melindungi kepentingan dan kepercayaan masyarakat dengan memelihara kesehatannya dan meningkatkan daya tahannya melalui, antara lain penyebaran risiko. Di dalam penanaman dananya dilakukan sedemikian rupa, agar tidak terpusat pada peminjam atau kelompok peminjam tertentu untuk menghindari terjadinya kredit macet. Karena dalam hal terjadi kredit macet akan menimbulkan kesulitan yang sangat besar akibatnya bagi keamanan dana masyarakat yang ada padanya.

Di samping itu, dengan adanya ketentuan ini diharapkan agar pemilik atau manajemen bank tidak memanfaatkan atau memperlakukan banknya sebagai sarana penghimpun dana bagi kepentingan usaha dari pemilik atau manajemen bank tersebut. Oleh karena itu, risiko pemberian kredit kepada debitur "orang dalam" adalah lebih tinggi dari risiko pemberian kredit "orang luar". Karena tingkat objektifitasnya dalam .menganalisa nasabah "orang dalam" dapat lebih rendah dibandingkan dengan "orang luar".

Posisi devisa netto, sebagaimana diatur dalam SK Direksi BI No. 23/75/KEP/DIR dan SE No. 23/17/U, masing-masing tertanggal 23 Februari 1991, yang menetapkan bahwa bank wajib untuk setiap saat memelihara selisih antar kewajiban devisa dengan tagihan devisa, maksimal sebesar persentase tertentu, yaitu setinggi-tingginya $20 \%$ dari modal bank, sedangkan untuk setiap jenis valuta asing setinggi-tingginya $25 \%$ dari modal. Sanksi atas pelampauan persentase tersebut di atas dikenai dalam rangka pembinaan dan pengawasan bank, karena bank harus memelihara posisi devisa netto hariannya dan melaporkannya 
kepada Bl setiap akhir minggu.

Dalam kaitannya dengan masalah pengawasan perbankan, maka antara Bank Syariah dengan Bank konvensional terdàpat perbedaan yang jelas. Bank Syariah di samping diawasi oleh $B I$ juga terdapat Dewan Pengawas Syariah sebagai-suatu badan yang mengawasi secara khusus hal-hal yang berhubungan dengan syariah dalam segala aktivitasnya. Sementara pada Bank Mandiri Konvensional hanya ada pengawas tunggal, yaitu $\mathrm{Bl}$.

Adanya dua lembaga pengawas bagi Bank Syariah ini, meskipun secara sepintas bidang tugasnya berlainan, namun tetap saja ada kemungkinan akan terjadinya benturan antara ketentuan pengawasan yang satu dengan yang lainnya. Pembahasan ini tidak dimaksudikan melibatkan tugas Dewan Komisaris yang melakukan fungsi pengawasan pula. Oleh karena sifatnya intern, di samping tentunya ada pada setiap usaha perbankan.

Dewan Pengawas Syariah adalah suatu badan yang dibentuk untuk mengawasi jalannya Bank Syariah agar dalam operasionalnya tidak menyimpang dari prinsip-prinsip syariah Islam. Dewan Pengawas Syariah pada Bank Syariah ini merupakan suatu bentuk perlindungan hukum dari segi syariah atau hukum Islam bagi para nasabahnya. Karena pada umumnya para nasabah Bank Islam mengambil keamanan syariah sebagai pertimbangan utama dalam menentukan lembaga keuangan mana yang akan diberi amanah pengelolaan dananya. ${ }^{18}$
Hal ini terutama bagi kelompok masyarakat muslim yang meragukan kehalalan pranata bunga yang diterapkan oleh perbankan konvensional, termasuk Bank konvensional. ${ }^{19}$ Oleh karena itu, sudah sewajarnyalah kepada para nasabah diberikan perlindungan hukum yang mereka butuhkan. Dengan demikian, dapat dikatakan bahwa Dewan Pengawas Syariah di setiap bank berdasarkan prinsip syariah seperti Bank Syariah merupakan bentuk perlindungan terhadap para nasabahnya.

Implementasi dari hal tersebut telah dituangkan sejak tahun 1992 dalam Peraturan Pemerintah No, 72 Tahun 1992 tentang Bank Berdasarkan Prinsip Bagi Hasil, secara tegas disebutkan bahwa:

1. Bank berdasarkan prinsip bagi hasil wajib memiliki Dewan Pengawas Syariah yang mempunyai tugas "melaksanakan pengawasan atas produk perbankan dalam menghimpun dana dari masyarakat dan menyalurkannya kepada masyarakat agar berjalan sesuai dengan prinsip syariah.

2. Pembentukan Dewan Syariah dilakukan oleh bank yang bersangkutan berdasarkan hasil konsultasi dengan lembaga yang menjadi wadah para ulama Indonesia.

\section{Mekanisme Pengawasan oleh Bank Indonesia}

Mengingat kedudukan bank yang merupakan bagian dari sistem keuangan dan perlunya kepentingan nasabah yang

\footnotetext{
${ }^{18}$ Arifin, Zainul, Memahami Bank Syariah (Jakarta: Alvabet, 1999), hlm. 32.

19Daud Ali, Muhhammad, Sistem Ekonomi Islam, Zakat dan Wakaf (Jakarta: UI Press, 1989), hlm. 56.
} 
mempercayakan dananya kepada bank dilindungi, maka tidak seperti halnya dengan perusahaan pada umumnya, kegiatan suatu bank harus terus dibina dan diawasi dari waktu ke waktu oleh Negara. ${ }^{20}$

Pembinaan dan pengawasan itu diwajibkan oleh Undang-undang No. 23 Tahun 1999 kepada Bl sebagai Bank Sentral untuk melaksanakannya.' Dalam rangka pelaksanaan tugas melakukan pembinaan dan pengawasan bank tersebut, $\mathrm{BI}$ diberikan kewenangankewenangan tertentu. Tujuan dari semua kegiatan dalam rangka pembinaan dan pengawasan bank yang dilakukan oleh $\mathrm{BI}$ itu adalah agar bank tidak mengalami kesulitan yang dapat membahayakan kelangsungan usahanya, yang pada gilirannya akan mengganggu stabilitas sistem keuangan dan merugikan para nasabah penyimpan dana. Oleh karena itu, bank harus selalu survive dari waktu ke waktu menjaga kesehatannya. ${ }^{21}$

Bl menetapkan ketentuan tentang kesehatan bank dengan memperhatikan aspek permodalan, kualitas asset, kualitas manajemen, rentabilitas, likuiditas, solvabilitas dan aspek lain yang berhubungan dengan usaha bank. Bank wajib memelihara kesehatan sesuai dengan ketentuan yang ditetapkan oleh $\mathrm{Bl}$ tersebut dan wajib melakukan usaha sesuai dengan prinsip kehati-hatian.

Di samping kewajiban memelihara kesehatan, bank jugawajib untuk memperhatikan kepentingan nasabah. Hal ini diatur dalam ketentuan-ketentuan sebagai berikut: ${ }^{22}$
1. Di dalam memberikan kredit melakukan kegiatan usaha lainnya bank wajib menempuh cara-cara yang tidak merugikan bank dan kepentingan nasabah. yang mempercayakan dananya kepada bank.

2. Untuk kepentingan nasabah, bank menyediakan informasi mengenai kemungkinan timbulnya risiko kerugian bagi transaksi nasabah yang dilakukan melalui bank. Informasi yang disediakan untuk nasabah tersebut adalah mengenai tingkat risiko dari kegiatan yang menjadi sasaran pengguna atau penempatan dana. Apabila informasi telah disediakan, maka bank dianggap telah melaksanakan ketentuan ini. Informasi tersebut perlu diberikan oleh bank, dalam hal bertindak sebagai perantara dalam melakukan penempatan dana dari nasabah atau membeli/menjual surat berharga untuk kepentingan dan atau perintah nasabahnya.

Kewajiban penyampaian keterangan dan penjelasan yang berkaitan dengan kegiatan usaha suatu bank kepada BI memantau keadaan dari suatu bank. Pemantauan keadaan bank perlu dilakukan dalam rangka melindungi dana masyarakat dan menjaga keberadaan lembaga perbankan.

Kepercayaan masyarakat terhadap lembaga perbankan hanya dapat ditumbuhkan, apabila lembaga perbankan dalam kegiatan usahanya selalu berada dalam keadaan sehat. Oleh karena itu, dalam rangka memperoleh

${ }^{20}$ Sutan Remi Sjahdeini, op. cit., hlm. 20. him. 3.

${ }^{21}$ Syafri Harahap, Sofyan, Unsur Agama Dalam Sistem Pengawasan (Medan: FE USU, Medan, 1990).

22Bank Indonesia, op. cit., hlm. 21-22. 
kebenaran atas laporan yang disampaikan oleh bank, Bl diberi wewenang untuk melakukan pengawasan melalui pemeriksaan buku-buku dan berkas-berkas yang ada pada bank. Pemeriksaan tersebut dilakukan oleh BI baik secara berkala maupun setiap waktu apabila diperlukan.

Kegiatan pengawasan bank dilakukan dalam upaya mewujudkan atau mendorong tumbuhnya sektor perbankan yang sehat dalam kaitannya dengan "Monetary Supervision" dan untuk melindungi kepentingan masyarakat pemilik dana yang menyimpan pada bank atau "Prudential Supervision". ${ }^{23}$ Monetary Supervision dimaksudkan untuk mengetahui dan mengukur kepatuhan serta keinginan bank dalam mendukung kebijaksanaan moneter. Sedangkan Prudential Superivision dimaksudkan untuk mengetahui dan mengukur bank apakah telah melakukan usahanya secara sehat. ${ }^{24}$

Praktik kegiatan pengawasan secara operasional mengalami perubahan atau perbedaan dari masa ke masa, tergantung pada perkembangan dan perubahan kondisi pada bank itu sendiri.

Dalam kaitan inilah BI tengah melakukan penyempurnaan sistem pengawasan bank, dari sistem compliance (kepatuhan pada regulasi) menjadi pengawasan berdasarkan risiko (risk based supervision), mengingat obyek dan cakupan pengawasan dan pemeriksaan bank bertambah luas dan rumit akibat bertambahnya jumlah bank yang baru termasuk Bank Perkreditan Rakyat, serta beraneka ragam jasa yang ditawarkan bank, maupun penggunaan teknologi komputer dalam upaya meningkatkan mutu pelayanan bertambah banyak pula. Pemyempumaan di bidang pemeriksaan bank meliputi aspek kebijaksanaan dan pedoman teknisnya, sedangkan di bidang pengawasan bank meliputi penyempumaan deteksi dini, sistem penilaian kesehatan bank dan cara penilaian solvabilitas bank.

Tugas pembinaan dan pengawasan bank di Indonesia masih dipercayakan kepada BI sebelum terbentuknya lembaga Otoritas Jasa Keuangan (OJK). Sebagai otoritas pengawas bank, BI dibekali dengan kewenangan yảng berkaitan perijinan atau memberikan rekomendasi kepada Menteri Keuangan yang mengeluarkan maupun mencabut ijin bank, mengeluarkan ketentuan-ketentuan yang memberikan landasan kerja yang sehat bagi perbankan, mengawasi pelaksanaan ketentuan-ketentuan yang berlaku dan memberikan pembinaan kepada bank-bank, baik dalam bentuk final terhadap pelanggaranpelanggaran yang dilakukan ataupun pemberian fasilitas-fasilitas bagi perbankan untuk mendorong perkembangan sistem perbankan yang sehat.

Landasan operasional yang perlu ditaati oleh bank, dimulai sejak awal pendiriannya dalam bentuk ketentuan perijinan. Sesuai dengan ketentuan di dalam pasal 15 ayat (1) Undang-undang No. 23 Tahun 1999 tentang Bank indonesia ditetapkan bahwa, dalam rangka mengatur dan menjaga kelancaran sistem pembayaran sebagaimana

${ }^{23}$ Dunbar, C.F., Theory and History of Banking, (New York: UPI Press, 1989), hlm. 9.

${ }^{24}$ Yuli Rinawati, "Tanggung Jawab BI Dalam Melaksanakan Fungsi Pengawasan dan Pembinaan terhadap Usaha Bankdi Kodia Semarang", Skripsi, Semarang, 1994, hlm. 62. 
dimaksudkan dalam Pasal 8 huruf $b, \mathrm{BI}$ berwenang:
a. Melaksanakan dan memberikan persetujuan dan ijin atas penyelenggaraan jasa sistim pembayaran.
b. Mewajibkan penyelenggara jasa sistem pembayaran untuk menyampaikan laporan tentang kegiatannya.
c. Menetapkan penggunaan alat pembayaran. ${ }^{25}$

Kewajiban untuk memperoleh ijin usaha sebagai bank atas penyelenggaraan jasa sistem pembayaran, dilakukan mengingat kegiatan bank menghimpun dana dari masyarakat. ${ }^{26} \mathrm{Di}$ samping persyaratan mengenai hal-hal yang bersangkutan atau berkaitan dengan pemberian ijin, seperti organisasi, permodalan, kepemilikan, keahlian di bidang perbankan, kelayakan rencana kerja dan halhal lain yang telah ditetapkan oleh Menteri Keuangan, pemberian ijin usaha bank dilakukan melalui 2 tahap : yakni persetujuan prinsip pada tahap untuk melakukan persiapan pendirian bank, dan tahap pembemberian ijin usaha, yaitu ijin yang diberikan untuk melakukan usaha setelah dilakukan persiapan.

Sementara itu, pembinaan dan pengawasan $\mathrm{Bl}$ atas bank dengan prinsip syariah tidak dimaksudkan untuk mengawasi pengawasan syariah yang mengandung unsur halal dan haram, akan tetapi dimaksudkan untuk menilai kewajaran dan kesehatan operasi bank dengan prinsip syariah agar tujuan pengawasan dan pembinaan secara keseluruhan dapat dicapai dengan sebaikbaiknya. ${ }^{27}$ Oleh karena itu, terhadap bank dengan prinsip syariah ditetapkan sistem dan prosedur pengawasan dan pembinaan yang sama dengan bank konvesional lainnya. Artinya, ketentuan yang berlaku bagi bank konvensional, berlaku pula terhadap bank dengan prinsip syariah. ${ }^{28}$

Undang-undang No. 23 Tahun 1999 tentang Bank !ndonesia juga memuat ketentuan mengenai dua jenis bank, yaitu Bank Umum dan Bank Perkreditan Rakyat dengan tidak membedakan antara bank-bank yang beroperasi secara konvensional dan dengan prinsip syariah. Oleh karena itu, pelaksanaan pembinaan dan pengawasan yang dilakukan oleh $\mathrm{BI}$ terhadap bank dengan prinsip syariah adalah sama dengan pelaksanaan pembinaan dan pengawasan bank konvensional (equal treatment). ${ }^{29} \mathrm{Namun}$ demikian pembinaan dan pengawasan bank dengan prinsip syariah yang merupakan penjabaran ketentuan-ketentuan yang pelaksanaannya berbeda dengan pengawasan bank konvensional adalah mengenai:

\section{Organisasi}

Salah satu perangkat organisasi bank dengan prinsip syariah adalah Dewan

${ }^{25}$ Undang-undang BI No. 23 Tahun 1999, (Jakarta: Sinar Grafika Offset, 1999).

${ }^{29}$ Marulak Pandede, op. cit., hlm. 32.

27 Siddiqi, Muhammad Nejatullah, Banking Without Intersest, Forowed, by Khurshid Ahmad, (London: The Islamic Foundation, 1993). him. 18.

${ }^{28}$ Syafi', Muchtar, "Manajemen Bank Syariah", dalam Buku Analisis Bank Syariah, (Jakarta: BP IPWI, 1995).

${ }^{29}$ Elias, G. Kazarian, Islamic Versus Traditional Banking: Financial Inovations In Egypt, (Ttp: Westview Press, 1997), hlm. 12. 
Pengawas Syariah yang berfungsi untuk memberikan penilaian apakah produk yang ditawarkan telah sesuai dengan syariah yang dikeluarkan dalam bentuk keputusan atau fatwa. Dewan Pengawas Syariah, sepanjang tidak bertentangan dengan ketentuan perbankan yang berlaku dan asas-asas pengembangan perbankan yang sehat. Dapat pula ditambahkan bahwa pengawasan terhadap kemumian operasi bank dengan prinsip syariah sepenuhnya menjadi tanggung jawab Dewan Pengawas Syariah beserta pemilik dan pengurus bank masing-masing. ${ }^{30}$ Dalam hal ini BI sebagai pembina dan pengawas bank hanya menilai apakah kegiatannya telah sesuai dengan prinsipprinsip usaha bank yang sehat, termasuk pertindungan terhadap nasabah.

2. Perijinan

Persyaratan dan tata cara pendirian Bank Umum dan Bank Perkreditan Rakyat konvensional berlaku untuk pendirian bank dengan prinsip syariah melalui tambahan persyaratan bahwa dalam Anggaran Dasar dan rencana kerja bank dengan prinsip syariah harus dinyatakan secara jelas mengenai rencana kegiatan usaha yang sepenuhnya atau sematamata berdasarkan prinsip syariah, jual-beli dan adanya Dewan Pengawas Syariah.

Bagi Bank Umum dan Bank Perkreditan Rakyat konvensional yang ingin mengubah pola operasinya menjadi bank dengan prinsip syariah atau sebaliknya, harus mengubah Anggaran Dasarnya dengan persetujuan dari $\mathrm{BI}$ terlebih dahulu sebelum dimintakan pengesahan Menteri Kehakiman.

3. Kualitas aktiva produk dan pembentukan cadangan.

Penilaian terhadap kualitas aktiva produktif bank erat kaitannya dengan penggolongan kolektibilitas aktiva produktif yang bersangkutan ke dalam kriteria lancar, kurang lancar, diragukan dan macet. Penetapan kriteria-kriteria tersebut bagi bank konvensional antara lain di dasarkan atas pembayaran bunga oleh nasabah, tetapi bagi bank dengan prinsip syariah yang beroperasi atas dasar prinsip bagi hasil keuntungan dan jual beli atau tanpa bunga, maka atas ketentuan penggolongan kolektibilitas yang berlaku bagi bank konvensional perlu dilakukan penyesuaian, khususnya mengenai penilaian kolektibilitas pemberian fasilitas pembiayaan. Pada hakikatnya pembiayaan yang dilakukan oleh bank dengan prinsip syariah dapat dikelompokkan pada dua golongan yaitu fasilitas pembiayaan yang pelunasannya dengan angsuran dan yang tanpa angsuran. Secara keseluruhan penilaian kolektibilitas aktiva produktif atau penanaman yang terdiri dari pembiyaan, surat berharga, penempatan dana pada bank lain, penyertaan, dan pembentukan cadangan aktiva yang diklasifikasikan bank dengan prinsip syariah apabila dibandingkan dengan bank konvesional.

${ }^{30}$ Zuhri, Muhammad, Riba dalam Al-Quran dan Masalah Perbankan (Sebuah Tilikan Antisipatif), (Jakarta: Raja Grafindo Perkasa, 1996), hlm. 53. 
4. Pelaporan

Sesuai dengan Undang-undang No. 23 Tahun 1999 antara lain ditetapkan bahwa setiap bank wajib menyampaikan kepada $\mathrm{BI}$ neraca yang dan peritungan laba atau rugi tahunan dan penjelasannya, serta laporan-laporan berkala lainnya dalam waktu dan bentuk yang ditetapkan oleh $\mathrm{Bl}$, seperti laporan mingguan atau laporan likuidasi minimum dan laporan data kliring, laporan bulanan atau laporan neraca bulanan bank-bank dan laporan perkreditan, laporan triwulanan yaitu laporan neraca dan perhitungan laba-atau rugi yang diumumkan, laporan semesteran yaitu laporan Dewan Komisaris bank mengenai hasil pengawasan terhadap jalannya usaha bank, laporan tahunan neraca dan laba atau rugi yang telan diaudit oleh akuntan publik, laporan rencana kerja tahunan, dan taporanlaporan lainnya yang bersifat insidental. Agar bank dengan prinsip syariah dapat menyampaikan laporan-laporan tersebut sebagaimana Bank konvensional, maka item-item dalam laporan bank dengan prinsip syariah perlu diubah.

\section{Mekanisme Pengawasan} oleh Dewan Pengawas Syariah

Bank Syariah, selain berfungsi menjembatani antara pihak yang kelebihan dana dengan pihak yang membutuhkan dana, .juga secara khusus mempunyai fungsi amanah. Artinya, berkewajiban menjaga dan bertanggung jawab atas keamanan dana yang disimpan dan siap sewaktu-waktu apabila dana tersebut ditarik kembali sesuai dengan perjanjian. ${ }^{3 t}$

Untuk menjaga fungsi amanah tersebut, perlu pengawasan yang melekat pada setiap orang yang terlibat di dalam aktivitas perbankan berupa motivasi keagamaan maupun pengawasan melalui kelembagaan. ${ }^{32}$ Di dalam menjalankan fungsi kelembagaan Bank Syariah, agar tidak menyimpang dari tuntunan syariah Islam, maka perlu adanya Dewan Pengawas Syariah. Dengan demikian, Dewan Pengawas Syariah merupakan suatu Dewan yang sengaja dibentuk untuk mengawasi jalannya Bank Syariah. Keharusan adanya Dewan Pengawas Syariah bagi Bank Syariah, sebagaimana disyaratkan oleh Undang-undang No. 23 Tahun 1999 tentang $\mathrm{Bl}$ yang memuat ketentuan tentang bank berdasarkan prinsip syariah.

Bagi Bank Syariah tugas dan wewenang Dewan Pengawas Syariah secara garis besar adalah melakukan pengawasan atas produkproduk perbankan, dalam rangka menghimpun dan menyalurkan dana untuk masyarakat agar sesuai dengan prinsip syariah Islam. Dalam petayanan produk dan jasa bank, baik dalam mobilisasi dana maupun dalam menanamkan dananya, Bank Syariah menawarkan produkproduk dan jasa perbankan yang sesuai dengan syariah Islam. ${ }^{33}$ Sebelum dipasarkan, produk-produk tersebut terlebih dahulu diteliti dan dipelajari oleh Dewan Pengawas Syariah.

31Warkum Sumitro, op. cit., hal. 22.

32/bid., him. 45.

${ }^{33}$ Sefuddin, Ah̆maid, Nilai-nilai Ekonomi lslam, (Jakarta: CV. Samudera, 1994), hlm. 47. 
Guna menunjang kelancaran pelaksanaan tugasnya dengan baik, dengan berpijak pada fungsi amanah tersebut di atas, maka keanggotaannya disyaratkan terdiri dari orangorang yang ahli syariah dan sedikit banyak menguasai Hukum Dagang positif serta berpengalaman dalam penyelenggaraan kontrak-kontrak bisnis.

Keberhasilan pelaksanaan tugas dan wewenang Dewan Pengawas Syariah ini sangat tergantung kepada independensinya di dalam membuat suatu putusan atau penilaian yang dibutuhkan sewaktu-waktu. Periu ditambahkan bahwa fungsi dan peranan Dewan Pengawas Syariah berbeda dengan fungsi dan peranan Dewan Komisaris. Fungsi dan Peranan Dewan Komisaris adalah melakukan pengawasan terhadap seluruh kegiatan operasional dan manajemen bank, sedangkan fungsi dan peranan Dewan Pengawas Syariah melakukan penelitian dan pengawasan atas produk-produk dan jasa perbankan yang yang dipasarkan agar sesuai dengan prinsip syariah. ${ }^{34}$ Pembentukan Dewan Pengawas Syariah dilakukan oleh bank yang bersangkutan berdasarkan hasil konsultasi dengan Majelis Úlama Indonesia (MUI).

Atas tuntutan perkembangan ekonomi bisnis, Dewan Pengawas Syariah menetapkan beberapa faktor tentang jasa-jasa Bank Syariah beberapa di antaranya:
1. Bank Syariah boleh melakukan transaksi jual beli surat berharga yang diedarkan oleh bank lain untuk tujuan usaha atas dasar Underlying Transaction. ${ }^{35}$ Dengan syarat bahwa transaksi jual beli surat berharga yang diedarkan oleh bank lain secara Repurchase Agreement berdasarkan harga tunai yang disepakati bersama dapat dipergunakan untuk pengadaan bahan baku, barang investasi dan usaha-usaha lainnya. Pelaksanaan transaksi jual-béli tersebut dilakukan melalui barik. koresponden dengan terlebih dahulu melakukan penilaian atas nasabah..$^{36^{\circ}}$

2. Bank Syariah boleh melakukan transaksi Bai'al-Inah ${ }^{37}$ atau pembiayaan ulang bagi nasabah yang telah dibiayai oleh bank lain dan hendak mengalihkan porto folio pembiayaannya ke Bank Syariah.

Transaksi Ba'ial-inah tersebut dapat dipergunakan untuk mengambil alih porto folio pembiayaan dari lembaga pembiayaan lain, baik untuk pembiayaan pengadaan bahan baku perdagangan atau barang investasi. Pelaksanaan transaksi al Ba'ial-inah tersebut hanya dapat dilakukan terhadap barangbarang dan jasa atau pelayanan. ${ }^{38}$

Sebagai lembaga perbankan yang menerapkan tata kerja spesifik, sudah barang tentu banyak masalah operasional yang dihadapi, baik masalah dari dalam maupun dari luar. ${ }^{39}$ Sebelum diresmikan Bank Syariah

\footnotetext{
34Prawiranegara, Syafruddin, Sistem Ekonomi /slam, (Jakarta: Publicita, 1997), hlm. 32.

${ }^{35}$ Harran, Sa'ad AS, Islamic Finance Partnership Financing, (Kuala Lumpur. Peladuk Publication, 1993), hlm. 44.

${ }^{36}$ Fatwa Dewan Pengawas Syariah No. 01/FAT-DPS/92.

${ }^{37}$ Habib, Shirazi, Islamic Banking, (Ttp:Lexis Law, 1990), him. 9.

${ }^{38}$ Fatwa Dewan Pengawas Syariah No. 02/FAT-DPS/92.

${ }^{39}$ Noor, Zainulbahar, Membangun Citra Lewat Pengamalan Syariah, (Jakarta: Grasindo, 1993), hlm. 61.
} 
di Indonesia, Sukamto, seorang pemerhati perbankan telah menengarai munculnya permasalahan seperti di atas. Lebih jauh dikatakan bahwa Bank Syariah adalah bank usaha keuangan yang beroperasi di negara yang mempunyai sistem perbankan berbeda. Bank Syariah menggunakan sistem bagi hasil keuntungan, sedangkan yang lain justru dalam kedudukan mayoritas menggunakan sistem bunga. Jika tidak berpegang teguh pada komitmen awal, maka dalam interaksi bisnisnya, sistem Bank Syariah bisa tercemar yang pada gilirannya dapat menimbulkan kerancuan tentang kehalalannya. ${ }^{40}$ Selanjutnya Sukamto juga menyatakan bahwa sebagai salah satu konsekuensinya, Bank Syariah di Indonesia tidak dapat pula berintegrasi dalam satu sistem dengan $\mathrm{BI}^{41}$ Pendapat Sukamto di atas didasarkan pada suatu pemikiran bahwa suatu sistem bagi hasil keuntungan yang berdasar pada prinsip syariah harus konsisten dengan komitmennya. Dalam menjaga kemurnian pranata bagi hasil keuntungan tersebut salah satu cara untuk menghindari tercemarnya dengan tidak berinteraksi dengan bank-bank non syariah atau konvensional.

Permasalahan menjadi tidak sederhana, karena BI yang nota bene juga beroperasi dengan sistem bunga, merupakani Bank sentral di Indonesia yang mempunyai kewenangan melakukan pengawasan dan pembinaan perbankan. Dengan demikian, ditambahkan oleh Sukamto, berarti Bank Syariah tidak dapat memperoleh kredit likuiditas dari $\mathrm{BI}$ apabila memerlukannya.

Dari pendapat tersebut $\mathrm{di}$ atas, permasalahannya sempat berkembang sampai pada pemikiran perlu adanya bank sentral syariah yang berwawasan syariah guna menopang beroperasinya Bank Syariah di Indonesia, 42

Konsekuensi dari diterimanya kehadiran perbankan dengan pranata bagi hasil keuntungan ini tidaklah sederhana. Karena Bank Syariah juga membutuhkan fasilitasfasilitas penunjang sebagaimana perbankan lainnya. Hal ini sangat penting bagi Bank Syariah agar dapat berkembang dan siap berkompetisi di era globalisasi. BI merupakan tangan kanan Pemerintah dalam kapasitasnya sebagai Bank Sentral terhadap urusan perbankan. Oleh karena itu, sangat diharapkan peranannya untuk mendampingi atau mem-back up agar Bank Syariah yang sudah menunjukkan kinerja-baiknya bisa tetap eksis. Mengingat sebagai bank yang relatif masih baru, disadari masih banyak mempunyai titik-titik rawan permasalahan yang menjadi tantangan tersendiri, baik bagi bank yang bersangkutan maupun bagi $\mathrm{BI}$, selaku Bank Sentral yang melakukan pengawasan dan pembinaan terhadap seluruh bank di Indonesia.

Salah satu persoalan yang perlu dikaji kaitannya dengan pengawasan perbankan

${ }^{40}$ Imam Zadjuli, Suroso, "Peran Perbankan Syariah Dalam Investasi Pembangunan", Makalah Seminar Ekonomi Islam Mendobrak Era Globalisasi, Surabaya, 1995, him. 10.

${ }^{41}$ Sukamto, "Bank Syariah di Indonesia, Problema Pengendalian dan Prospeknya," Ceraman Dies Natalis ke 48 Ull, Yogyakarta, 1992, hlm. 4.

42Warta Ekonomi, No. 42TH.VI/6. 13 Maret 1995, hlm. 17. 
dalam rangka menjaga kelangsungan Bank Syariah agar tetap eksis dalam kondisi sehat, yakni pada aspek likuiditasnya. Persoalan bagaimana menghadapi kemungkinankemungkinan timbulnya permasalahan di sekitar likuiditas Bank Syariah perlu dipersiapkan sedini mungkin. ${ }^{43}$ Persoalan manajemen likuiditas adalah suatu proses manajerial yang diarahkan untuk mengelola kemampuan pendanaan bank (cash-flow) untuk setiap saat dapat memenuhi funding risk yang muncul sebagai akibat adanya pola penarikan dana yang tidak menentu dan kemampuan untuk mengantisipasi interest rate akibat adanya gapping atau mis-match antara jatuh waktu asset dan liability bank yang terjadi secara terus-menerus.

Di setiap negara tempat Bank Syariah beroperasi terdapat landasan hukum (legal foundation) ${ }^{4}$ bagi keberadaan bank tersebut. Sewajarnya bank sentral bersangkutan memberikan pelayañan yang sama (equal treatment) seperti bank konvensional lainnya menyangkut operasional dan pengawasan Bank Syariah di negaranya. Mengingat konsep bank Syariah merupakan sesuatu yang baru, peranan bank sentral dalam perkembangan bank Syariah menjadi sangat penting.

Pandangan Chapra dalam bukunya Toward a Just Monetary System dalam hal ini (that the Central Bank should be pivot of the Islamic banking system, because only through its conscientious and creative effort can the Is- lamic money and banking system achieve its self actualization) merefleksikan pendapat yang hidup di kalangan praktisi perbankan:Islam dan bank sentral di negara-meraga tersebut. ${ }^{45}$ Di mana seperti diketahui bahwa jauh sebelum UU No. 23 Tahun 1999 dikeluarkan sebagai pengganti UU No. $\$ 13$ Tahun 1968 tentang BI, BI telah secara sungguh-sungguh mempelajari seluk-beluk operasional Bank Syariah di Timur Tengah, Pakistan dan Malaysia.

Pandangan yang sama tentang peran bank sentral tersebut pernah dinyatakan oleh Gubemur BI dalam Keynote Speech-nya pada konferensi ke IX para ahli Bank Syariah yang diselenggarakan oleh $\mathrm{BI}$ dan Intemational Association of Islamic Bank (IAIB) dengan menekankan pentingnya bagi $\mathrm{BI}$ untuk mengeluarkan fasilitas likuiditas yang dapat diberlakukan pada Bank Syariah (to create liquidity facilities that are compatible with Syariah Banks). ${ }^{46}$

Rata-rata bank Syariah menghadapi masalah likuiditas terutama dalam penyediaan dana sangat segera dalam memenühi kewajiban jatuh temponya. Hal ini terutama disebabkan oleh keterbatasan karena tidak dapat melakukan peminjaman dana dengan sistem bank konvensional yang ada. $\mathrm{Di}$ samping itu fasilitas yang belum tersedia:dari bank sentralnya untuk menutupi kebutuhan semacam itu. ${ }^{47}$

\footnotetext{
${ }^{43}$ Kahf, Monzer, Ekonomilslam,(Yogyakarta: Pustaka Pelajar, 1995), hlm. 23.

${ }^{4} F u a d$ Al Omar, Muhammad Abdel Haq, Islamic Banking: Theory, Practice and Challenges,(Ttp: Martin's Press Inc., 1996), him. 30.

${ }^{45}$ Chapra, M. Umer, Al Qur'an Menuju Sistem Moneter Yang Adil, Yogyakarta: PT. Dana BhaktiPrima Yasa; 1997), him. 21.

${ }^{46}$ Mahmood, Farouqi, Islamic Banking and Investment: Challenge and Opportunity, (Ttp: Routtedge, 1995).

${ }^{47} /$ bid., hlm. 97.
} 
Dengan demikian adanya pengembangan instrumen likuiditas yang dibahas dalam konferensi ke IXitu menjadi sangatlah penting, mengingat bahwa peran pokok Bank Syariah adalah sebagai perantara dalam arus dana seperti juga peran dari bank-bank konvensional lainnya. Hal ini dapat dimengerti lantaran fasilitas dan instrumen likuiditas yang ada di Bl seperti Surat Berharga Pasar Uang (SBPU) dan Sertifikat BI (SBI), terutama ditujukan untuk perbankan non syariah. Konsekuensinya, BI perlu menciptakan fasilitas likuiditas yang sesuai dengan prinsip

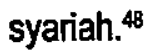

Persoalan likuiditas merupakan hal yang tidak saja diharapkan oleh bank-bank Islam di Indonesia, manun juga diharapkan oleh Bank Syariah di negara-negara lain. Tanpa adanya peran serta Bank Sentral dalam menyediakan instrumen-instrumen likuiditas yang sesuai syariah perkembangan bank-bank Islam tidak akan secepat yang diharapkan.

\section{Simpulan}

Mekanisme pengawasan antara Dewan Pengawas Syariah dan BI terhadap Bank Syariah, terdapat perbedaan mengenai aspek pengawasannya. Dewan Pengawas Syariah melakukan pengawasan, di mana sebelum dipasarkannya produk-produk perbankan terlebih dahulu diteliti dan dipelajari oleh Dewan Pengawas Syariah agar sesuai dengan ketentuan syariah Islam. Sedangkan mekanisme pengawasan yang dilakukan oleh BI berkaitan dengan kesehatan Bank Syariah melalui pemeriksaan buku-buku dan berkasberkas yang ada pada Bank Syariah. Pemeriksaan tersebut dilakukan oleh BI baik secara berkala maupun setiap waktu bila diperlukan.

Peran Bank Syariah dalam rangka pelaksanaan fungsi pengawasannya, yaitu melakukan pengawasan atas produk-produk perbankan, sebagai upaya menghimpun dan menyalurkan dana untuk masyarakat agar sesuai dengan syariah Islam, sedangkan BI berperan memperhatikan aspek permodalan, kualitas asset, kualitas manajemen, rentabilitas, likuiditas, solvabilitas dan aspek lain yang berhubungan dengan usaha Bank Syariah sesuai dengan prinsip kehati-hatian. $\square$

\section{Daftar Pustaka}

Abdul Qadir, Banaga, Graham H. Ray, Cyril R, Tom Kins. Ekstemal Audit And Corporate Govemance In Islamic Banks: A Joint Practitioner-Academic Research. Ttp: Ashgate Publishing Company, 1994.

Afif, Faisal, dkk. Strategi dan Operasioanl Bank. Bandung: Eresco, 1996.

Arifin, Zainul. Memahami Bank Syariah. Jakarta: Alvabet, 1999.

Bank Indonesia. Hal-hal Pokok Dalam Undangundang No. 7 Tahun 1992 Tentang Perbankan. Jakarta: Tp, 1992.

Chapra, M. Umer. Al Qur'an Menuju Sistem Moneter yang Adil. Yogyakarta: PT. Dana Bhakti Prima Yasa, 1997.

${ }^{40}$ Hidayat, Muhammad R., Ekonomi Kerakyatan Dalam PerspektifMuamalah, (Yogyakarta: Tp, 1999), hlm. 21. 
Daud Ali, Muhammad. Sistem Ekonomi Islam, Zakat dan Wakaf. Jakarta: UI Press, 1989.

Djumhana, Muhammad. Hukum Perbankan di Indonesia. Bandung: Citra Aditya Bakti, 1989.

Dunbar, C.F. Theory and History of Banking, New York: UPI Press, 1989.

Elias, G. Kazarian. Islamic Versus Traditional Banking: Financial Inovations in Egypt, Ttt: Westview Press, 1997.

Fatwa Dewan Pengawas Syariah No. 02/FATDPS/92.

Fuad Al Omar, Muhammad Abdel Haq. Islamic Banking: Theory, Practice and Challenges. Ttt: Martin's Press Inc., 1996.

Habib, Shirazi. Islamic Banking. Ttt: Lexis Law, 1990

Harran, Sa'ad AS. Islamic Finance Partnership Financing. Kuala Lumpur: Peladuk Publication, 1993.

Hidayat, Muhammad R. Ekonomi Kerakyatan Dalam PerspektifMuamalah. Yogyakarta: Tp, 1999.

Imam Zadjuli, Suroso. Peran Perbankan Syariah Dalam Investasi Pembangunan, Makalah Seminar Ekonomi Islam Mendobrak Era Globalisasi. Surabaya: Tp, 1995.

Kahf, Monzer. Ekonomi Islam. Yogyakarta: Pustaka Pelajar, 1995.

Mahmood, Farouqi. Islamic Banking and Investment: Challenge and Opportunity, Ttt: Routledge, 1995.
Muhammad Hadi Subhan. Rentabilitas Perbankan Dengan Sistem Bagi iHasil Dan Relevansi Asas Kehati-hatian Dalam Proses Pemberian Kredit Tanpa Agunan. Surabaya: FH. UNAIR, , 1994.

Noor, Zainulbahar. Membangun Citra Lewat Pengamalan Syariah. Jakarta: Grasindo, 1993.

Pardede, Marulak. "Tinjauan Terhadap Metoda Bank Indonesia Dalam Menciptakan Perbankan yang Profesional dan Sehat." Newsletter No. 19N/Desember/1994.

Prawiranegara, Syafruddin. Sistem Ekonomi Islam. Jakarta: Publicita, 1997.

Rahman, Hasanudin. Aspek-aspek Hukum Pemberian Kredit Perbankan di Indonesia. Bandung: Citra Aditya Bhakti, 1995.

Remi Sjahdeni. "Bank Indonesia Penggerak Utama Reformasi Peraturan Perundangan Perbankan." Orasi, UNAIR, Suarabaya, 1996.

Sefuddin, Ahmad. Nilai-nilai Ekonomi Isiam. Jakarta: CV. Samudera, 1994.

Siddiqi, Muhammad Nejatulla., Banking Without Intersest, Forowed. by Khurshid Ahmad. London: The Islamic Foundation, 1993.

Subardjo Joyo Sumarto. Pengawasan dan Pembinaan Bank. Jakarta: Bank Indonesia, 1993.

Sukamto. "Bank Syariah di Indoneśia, Problema Pengendalian dan Prospeknya." Ceramah Dies Natalis ke 48 iUll, Yogyakarta, 1992. 
Suradi. "Peranan Bank Perkreditan Rakyat Berdasarkan Prinsip Bagi Hasil Bagi Pengusaha Kecil di Daerah Istimewa Yogyakarta." Tesis, Program Pasca Sajjana UGM, Yogyakarta, 1997.

Sutan Remi Sjahdeni. "Sudah Memadaikah Perlindungan Yang Diberikan Oleh Hukum Kepada Nasabah Penyimpan Dana." Orasi IImiah Dies Natalis XV Lustrum VIII UNAIR, Surabaya, 1994.

Syafi'i, Muchtar. "Manajemen Bank Syariah."

Dalam Buku Analisis Bank Syariah. Jakarta: BP IPWI, 1995.

Syafri Harahap, Sofyan. Unsur Agama Dalam Sistem Pengawasan. Medan: FE USU, 1990.
Undang-undang BI No. 23 Tahun 1999. Sinar Grafika Offset, Jakarta 1999.

Warkum Sumitro. Asas-asas Perbankan Islam dan Lembaga-lembaga Terkait Di Indonesia. Jakarta: Raja Grafindo Persada, 1992.

Warta Ekonomi, №. 42THH.VI/6. 13 Maret 1995.

Wijanarko. Hukum dan Ketentuan Perbankan di Indonesia. Jakarta: Grafiti, 1993

Yuli Rinawati. “Tanggung Jawab BI Dalam Melaksanakan Fungsi Pengawasan dan Pembinaan terhadap Usaha Bankdi Kodia Semarang." Skripsi, Semarang, 1994.

Zuhri, Muhammad. Riba dalam AI Qur'an dan Masalah Perbankan (Sebuah Tilikan Antisipatif). Jakarta: Raja Grafindo Perkasa, 1996.

\section{$\infty \odot$}

